\title{
Rancang Bangun Alat Monitoring Pergerakan Objek pada Ruangan Menggunakan Modul RCWL 0516
}

\author{
Qurotul Aini ${ }^{1}$, Untung Rahardja ${ }^{2}$, Harries Madiistriyatno ${ }^{3}$, dan Azharul Fuad ${ }^{4}$ \\ ${ }^{1,2}$ Sistem Informasi STMIK Raharja \\ JL. Jenderal Sudirman No.40 Modern Cikokol, Tangerang, Indonesia \\ ${ }^{3}$ Fakultas Ekonomi dan Bisnis Y.A.I \\ Jl. Diponegoro No. 74, Jakarta Pusat, Indonesia \\ ${ }^{4}$ Sistem Komputer STMIK Raharja \\ JL. Jenderal Sudirman No.40 Modern Cikokol, Tangerang, Indonesia \\ aini@raharja.info ${ }^{1}$,untung@raharja.info ${ }^{2}$,harries.madi@gmail.com ${ }^{3}$,azharul@raharja.info ${ }^{4}$
}

\begin{abstract}
Nowdays, along with the development of electronics and computers, the crime rate increases rapidly. today almost all systems and security tools are using electronic devices such as computers and microcontrollers. Every electronic device always has weakness, such as camera needs the light to capture images, Passive InfraRed (PIR) sensor only has ability for human body temperature detection, Short Message Service (SMS) which its services depend on prepay credit and cellular operator signal range. Based on the problem, a radio-based doppler radar detection tool was developed using $R C W L 0516$ module. In this research will be discussed the use of RCWL 0516 sensor as main module to detect the movement of the object by measuring the microwave wave value that displayed on the user gadget by using Blynk application. The digital communication is used and implemented on Arduino Uno microcontroller. The data is sent and will be displayed on the gadget through Blynk application in the form of graph in real time and connect to the internet using ESP8266 as a connection receiver. The results obtained that the RCWL 0516 module has a better accuracy level in detecting movement than other motion detection sensors such as PIR sensors and ultrasonic sensors.
\end{abstract}

Keywords-Module RCWL 0516, Arduino Uno, ESP8266, Blynk apps

Abstrak- Seiring dengan perkembangan zaman, perkembangan elektronika dan komputer sangatlah pesat maka tingkat kejahatanpun semakin meningkat. Saat ini hampir semua sistem dan alat keamanan apapun menggunakan alat-alat elektronika seperti komputer hingga mikrokontroller. Setiap alat elektronika memiliki kelemahan, seperti kamera membutuhkan cahaya untuk mendeteksi, sensor Passive Infra Red (PIR) hanya mampu mendeteksi suhu tubuh manusia, Short Message Service (SMS) bekerja bergantung layanan dan jangkauan sinyal operator serta pulsa. Berdasarkan permasalahan tersebut dibuatlah alat deteksi gerak berbasis radar doppler gelombang radio menggunakan modul RCWL 0516. Pada penelitian ini, penggunaan sensor RCWL 0516 sebagai modul utama untuk mendeteksi pergerakan objek dengan cara mengukur dari nilai gelombang microwave dengan memanfaatkan aplikasi Blynk yang bersifat mudah digunakan sebagai tampilan pada gadget pengguna. Komunikasi yang digunakan adalah komunikasi digital dan digunakan mikrokontroler Arduino Uno. Data dikirim dan akan ditampilkan pada gadget melalui aplikasi Blynk berupa grafik yang diakses secara langsung dan terhubung internet dengan menggunakan ESP8266 sebagai penerima koneksi pada alat. Hasil yang diperoleh adalah modul RCWL 0516 memiliki tingkat keakuratan lebih baik dalam mendeteksi pergerakan dibanding sensor pendeteksi gerak lainnya seperti sensor PIR dan sensor ultrasonic.

Kata kunci-Modul RCWL 0516, Arduino Uno, ESP8266, aplikasi Blynk

\section{Pendahuluan}

Objek bergerak merupakan satu aspek yang penting dalam analisis pergerakan. Dalam beberapa tahun belakangan ini semakin mendapat perhatian disebabkan semakin berkembangnya aplikasi-aplikasi pengawasan atau kontrol sepertiaplikasi pengawasan lalulintas, pengawasan keselamatan, dan sebagainya.

Dalam ilmu teknologi sudah banyak penemuan yang sangat bermanfaat bagi manusia salah satunya yaitu modul sensor. Modul sensor adalah alat yang digunakan untuk mendeteksi dan sering berfungsi untuk mengukur magnitude. Modul sensor adalah sejenis transduser yang digunakan untuk mengubah variasi mekanis, panas, magnetis, kimia dan cahaya menjadi arus listrik dan tegangan. Kemajuan ilmu teknologi tersebut sangat berguna untuk membuat sebuah rancang bangun alat. Dalam penelitian ini akan dibahasrancang bangun alat deteksi pergerakan objek dalam ruangan menggunakan modul RCWL 0516. Sistem ini dirancang dengan perangkat elektronika yang terdiri dari modul RCWL 0516 yang 
merupakan modul sensor penggerak berbasis radar dopplergelombang mikro, modul WiFi ESP8266 untuk penerima koneksi internet pada alat, dan kit mikrokontroler ArduinoUno.Alat ini dirancang untuk dapat mengidentifikasi keberadaan manusia danterhubung kepada pengguna dari jarak jauh.

Salah satu yang digunakan sebagai sensor deteksi pergerakan objek adalah sensor passive infrared (PIR). Alat pendeteksi pergerakan pada sebuah ruangan dapat mengggunakan sensor PIR dengan komponen-komponen pembantu lainnya [1]. Sensor infrared dapat mendeteksi pergerakan manusia yang diimplementasikan dengan menggunakan metode Cluster Based [2]. Sensor lain yang dapat membaca pergerakan adalah sensor ultrasonik. Referensi [3] memanfaatkan sensor ultrasonik untuk membaca pergerakan, namun lebih ke arah jarak benda yang bergerak.

Setiap alat elektronika memiliki kelemahan, seperti misalnya kamera membutuhkan cahaya untuk mendeteksi, sensor PIR hanya mampu mendeteksi suhu tubuh manusia, serta Short Message Service (SMS) bekerja bergantung layanan dan jangkauan sinyal operator serta pulsa. Berdasarkan dari kelemahan tersebut maka dibuat penelitian rancang bangun alat deteksi pergerakan pada ruangan menggunakan modul RCWL 0516 dan didukung dengan interface berbasis online. Pentingnya dashboard pada suatu sistem untuk penyampaian informasi [4], maka digunakan aplikasi Blynk sebagai media informasi berbasis online [5].

\section{METODEPENELITIAN}

Metode penelitian yang digunakan dalam penelitian ini adalah metode observasi, studi pustaka, perancangan dan pengujian. Metode observasi adalah metode pengumpulan data melalui pengamatan atau peninjauan secara langsung di lapangan atau lokasi penelitian [6]. Teknik observasi dalam penelitian ini digunakan untuk menentukan desain dan tingkat keakurasian sebelum melakukan pembuatan alat. Observasi data dilakukan dengan cara mencari sumber, mengkaji teori serta studi lapangan mengenai data yang akan digunakan sebagai acuan dalam pembuatan alat. Literatur review adalah mengidentifikasikan kesenjangan (identify gaps), menghindari pembuatan ulang (reinventing the wheel), mengidentifikasikan metode yang pernah dilakukan, meneruskan penelitian sebelumnya, serta mengetahui orang lain yang spesialisasi dan area penelitiannya sama di bidang ini [7].

Skema rangkaian alat dan diagram blok bagian hardware ditunjukkan pada Gambar 1 dan Gambar 2. Rancangan terdiri atas komponen mikrokontroler, adapterWiFi (ESP8266), battery Li-ion 7,4volt, dan sensor RWCL 0516.

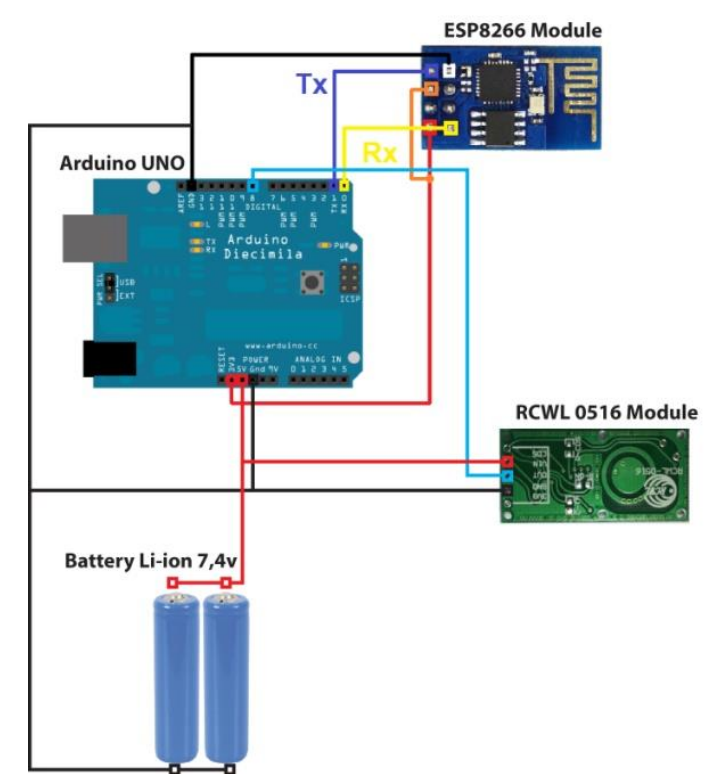

Gambar 1. Skema rangkaian alat pendeteksi pergerakan objek

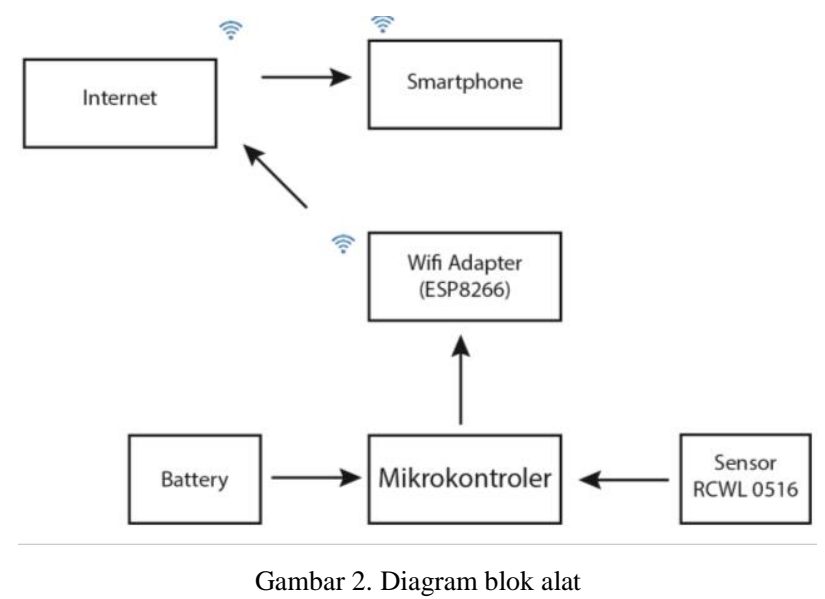

\section{1) Mikrokontroler}

Kit mikrokontroler yang dipilih adalah Arduino. Arduino merupakan pengendali mikro single-board yang bersifat opensource, diturunkan dari wiring platform, dirancang untuk memudahkan penggunaan elektronik dalam berbagai bidang. Hardware Arduino adalah mikrokontroler ATmega 328 dan memiliki bahasa pemrograman sendiri [8].Alasan pemilihan Arduino adalah karena mudah dalam penggunaan program yang bersifat open-source dan memiliki pin I/O yang memadai. Susunan kaki-kaki board Arduino ditunjukkan pada Gambar 3. 


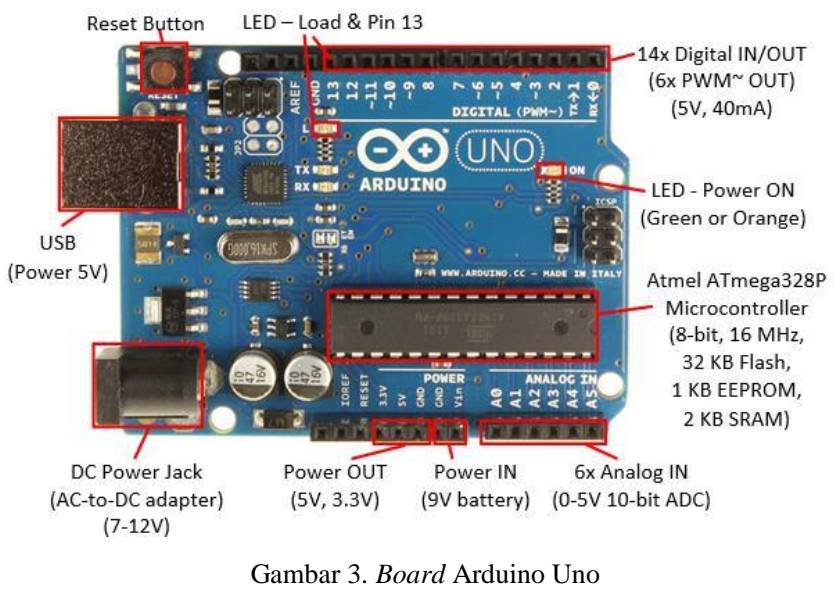

2) Modul RCWL 0516

RCWL 0516 adalah modul sensor gerak gelombang mikro radar doppler, bekerja dengan membaca gelombang suara disekitar dan sensor ini dapat membaca pergerakan hingga 4 meter jarak objek terhadap sensor. Bentuk fisik Modul RCWL 0516 ditunjukkan pada Gambar 4.
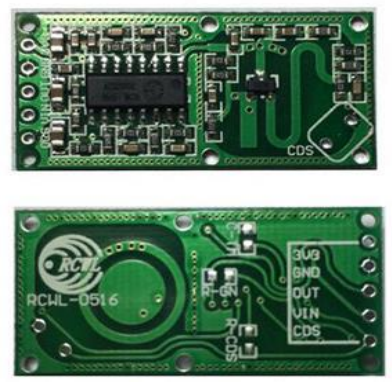

Gambar 4. Modul RCWL 0516

\section{3) Modul ESP8266}

ESP8266 memiliki kemampuan pemrosesan dan penyimpanan papan yang memungkinkan untuk diintegrasikan dengan sensor dan perangkat spesifik aplikasi lainnya melalui GPIO dengan pengembangan minimal di depan dan pemuatan minimal selama waktu proses. Dengan tingkat tinggi pada integrasi chip, yang meliputi saklar antena, konverter manajemen daya, dan membutuhkan sirkuit eksternal lebih sedikit, dan termasuk modul ujung depan, dirancang untuk menempati area PCB yang lebih sedikit [9]. Bentuk fisik modul ESP8266 ditunjukkan pada Gambar 5.

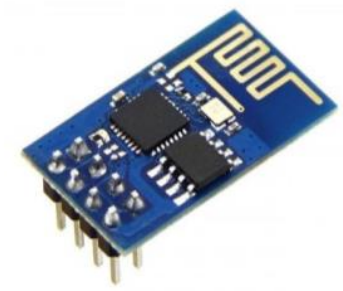

Gambar 5. Modul ESP8266

\section{4) Software}

Program aplikasi Blynk pada chip mikrokontroler dengan menggunakan aplikasi pengembangan board Arduino yang sudah di-install ESP8266 Core for Arduino. Flowchart aplikasi monitoring jarak jauh ditunjukkan pada Gambar 6 .

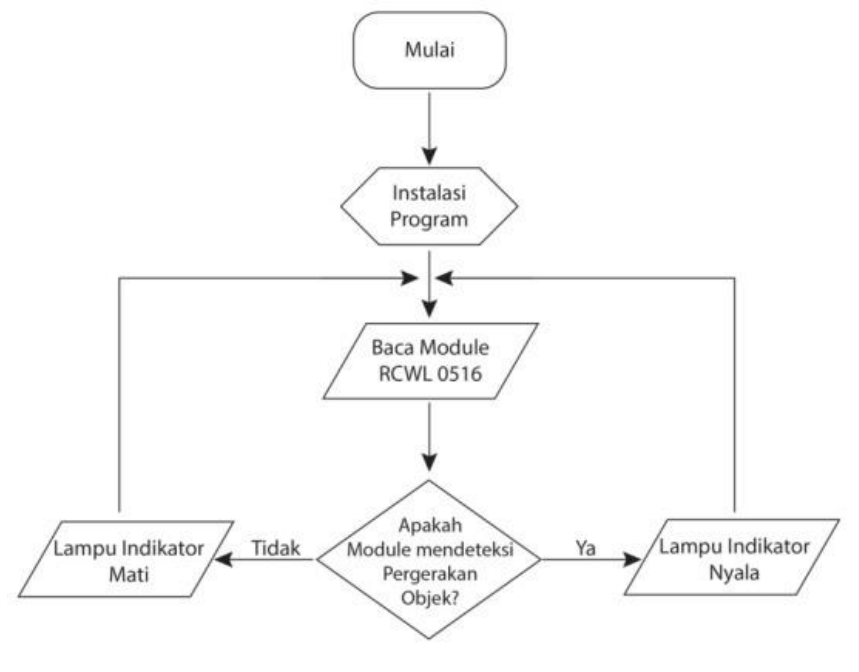

Gambar 6. Flowchart aplikasi

Berdasarkan flowchart pada Gambar 6, program akan mengirimkan data berupa output digital dari modul RCWL 0516 melalui modul ESP8266. Spesifikasi software yang digunakan adalah sebagai berikut :

- Program pada mikrokontroler Arduino menggunakan bahasa Arduino dengan sejumlah library terkait, seperti ESP8266.

- Program pada smartphone menggunakan aplikasi yang sudah tersedia untuk mengendalikan perangkat melalui jaringan WiFi (berbasis ESP8266) yaitu Blynk.

5) Arduino IDE

Source code untuk dapat berkomunikasi antara mikrokontroler dengan modul WiFi dan terhubung dengan aplikasi Blynk dapat diunduh di laman https://github.com/esp8266/ sedangkan library Blynk dapat diunduh di laman https://github.com/blynkkk/blynk-library yang ditambahkan ke Arduino IDE, untuk pemasangan library dijelaskan pada laman https://www.arduino.cc/en/Guide /Libraries. Library ini berfungsi untuk terhubung dengan server Blynk yang berkomunikasi lewat internet dengan module ESP8266. Halaman Kerja Arduino IDE ditunjukkan pada Gambar 7. Penggunaan library pada sketch (source code) diperlihatkan pada listing program berikut ini:

\#define BLYNK_PRINT Serial

\#include <ESP8266WiFi.h>

\#include <BlynkSimpleEsp8266.h>

char auth[] = "462e457a5eff43b4b9e8a670243xxxxx"; //token blynk

int ip $=8 ; / /$ pin input

int $\mathrm{val}=0$;

int led $=13 ; / /$ pin output

void setup() \{ 
Serial.begin(9600);

pinMode (ip, INPUT);

pinMode (led, OUTPUT);

Blynk.begin(auth, "RAHARJA", " "); I/koneksi WiFi

\}

void loop() \{

val = digitalRead $(i p)$;

Serial.println(val, DEC);

if $($ val $>0)$

i

$$
\text { \} }
$$

digitalWrite(led, $\mathrm{HIGH)}$;

else

i

\}

digitalWrite(led, LOW);

delay(1000); //waktu delay

Blynk.run();\}

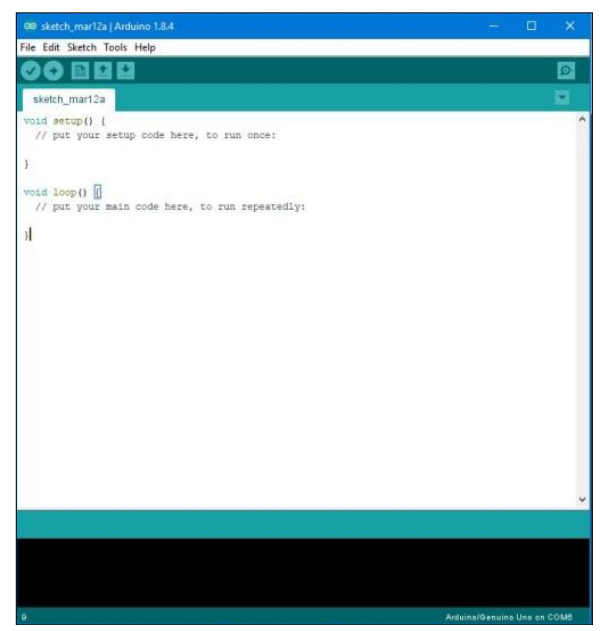

Gambar 7. Halaman kerja Arduino IDE

6) Aplikasi Blynk

Blynk merupakan aplikasi yang berbasis IOS atau Android untuk mengontrol mikrokontroler berupa Arduino melalui internet. Aplikasi Blynk dapat membantu admin dalam memonitoring sesuatu dengan praktis. Blynk dirancang untuk Internet of Things. Dapat mengontrol perangkat keras dari jarak jauh, dapat menampilkan data sensor, dapat menyimpan data, memvisualisasikannya, dan melakukan banyak hal lainnya [10]. Tampilan aplikasi Blynk ditunjukkan pada Gambar 8.

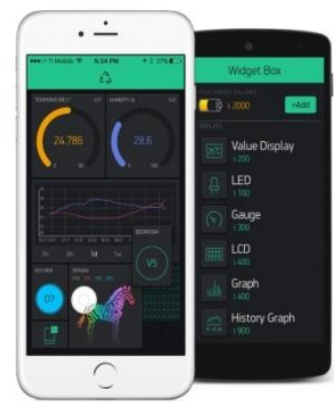

Gambar 8. Tampilan Blynk pada gadget

\section{HASIL DAN PEMBAHASAN}

Hasil dan pembahasan penelitian bertujuan untuk mengetahui kinerja alat atau tingkat kelayakan dan keakurasian kerja sensor. Penilaian tingkat kelayakan didasarkan pada aspek-aspek yang ada yaitu dari segi tampilan, kemudahan penggunaan serta manfaat dari alat yang dibuat. Jika dibandingkan dengan sensor pendeteksi gerak lainnya seperti sensor PIR atau sensor ultrasonik seperti pada penelitian sebelumnya, sensor RCWL0516 ini memiliki keakuratan dalam pendeteksian gerak.

Hasil pengujian terhadap sensor RCWL 0516 ditunjukkan dalam bentuk grafik seperti ditunjukkan pada Gambar 9. Fitur Arduino IDE "Plotter" mulai otomatis dan output analog pada arduino memiliki range 0 sampai 4096 pada jalur 12 bit, dalam hal ini ditunjukkan dalam grafik dari 0 hingga 4500.Warna hijau adalah output digital (dalam hal ini LOW / OFF) dan warna merah adalah sinyal analog.

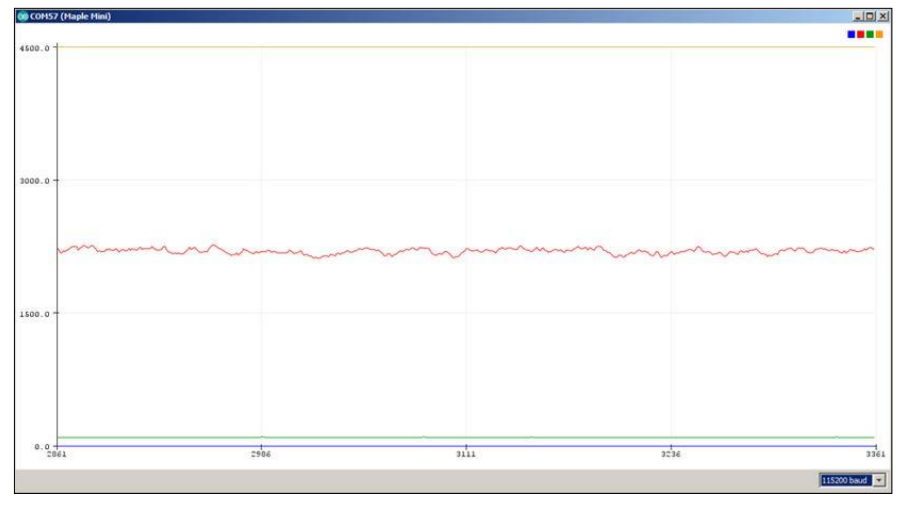

Gambar 9. Tampilan Plotter pada Arduino IDE

\section{A. Pengujian modul RCWL 0516}

Percobaan pertama berupa pelambaian tangan dihadapan sensor berjarak 2 meter dengan sudut $25^{\circ}$ dari sensor (Gambar 10). Gerakan dapat dideteksi sensor dan didapatkan grafik hasil pengujian seperti ditunjukkan pada Gambar 11.

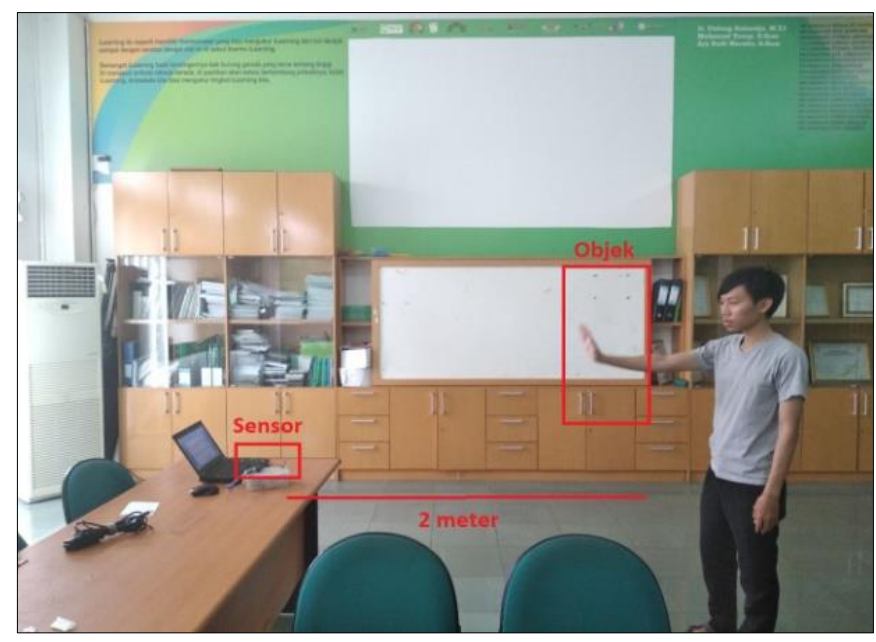

Gambar 10. Uji coba pertama dengan melambaikan tangan 
Gambar 11 merupakan grafik deteksi pergerakan yang ditunjukkan oleh garis merah, dimana YAxis merupakan batas maksimum output pada Arduino yang memiliki range 0 sampai 4096 pada jalur 12 bit. Dapat disimpulkan bahwa sensor membaca gerakan kecil seperti lambaian tangan secara continues.

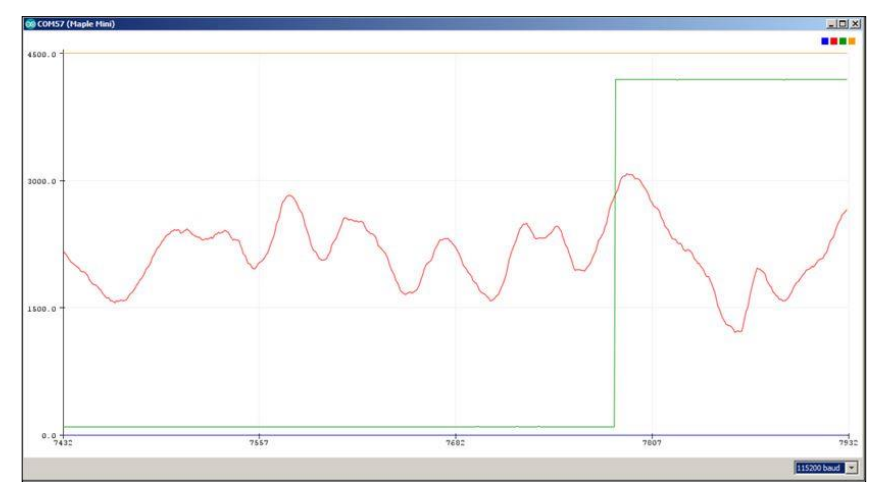

Gambar 11. Tampilan plot dari hasil uji coba pertama

Percobaan kedua berupa berjalan kearah sensor berjarak 4 meter dengan posisi sejajar dengan sensor dan berhenti (Gambar 12). Hasil yang diperoleh berupa grafik seperti ditunjukkan pada Gambar 13. Percobaan kedua dengan gerakan yang berbeda yaitu berjalan mendekati sensor dan didapatkan hasil grafik mendekati hasil maksimum Yaxis (Gambar 13). Dapat disimpulkan bahwa dalam percobaan ini gerak jalan manusia sudah dianggap pergerakan yang besar untuk sensor ini.

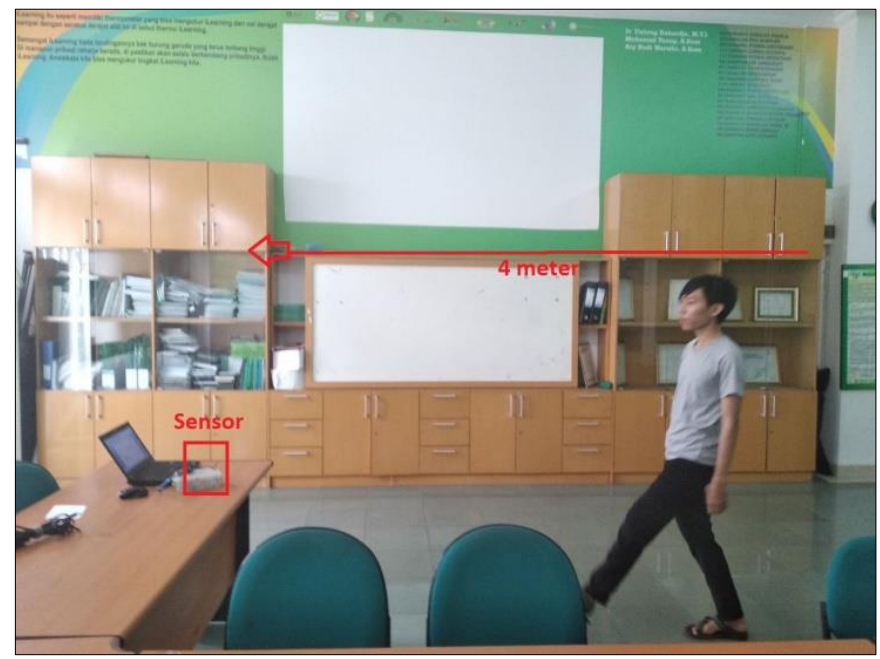

Gambar 12. Uji coba kedua dengan berjalan ke arah sensor

Percobaan ketiga adalah menjatuhkan benda berupa gumpalan kertas dari ketinggian 1,5 meter yang berhadapan berlawanan dengan sensor (Gambar 14). Hasil yang diperoleh berupa grafik seperti ditunjukkan pada Gambar 15. Percobaan ketiga ditujukan untuk menguji tingkat sensitivitas pada pergerakan yang lebih kecil. Hasilnya mengejutkan karena sensor masih dapat membacanya, terlihat pada Gambar 15 dimana garis merah tidak bernilai nol. Dapat disimpulkan bahwa sensor ini memiliki sensitivitas yang tinggi.

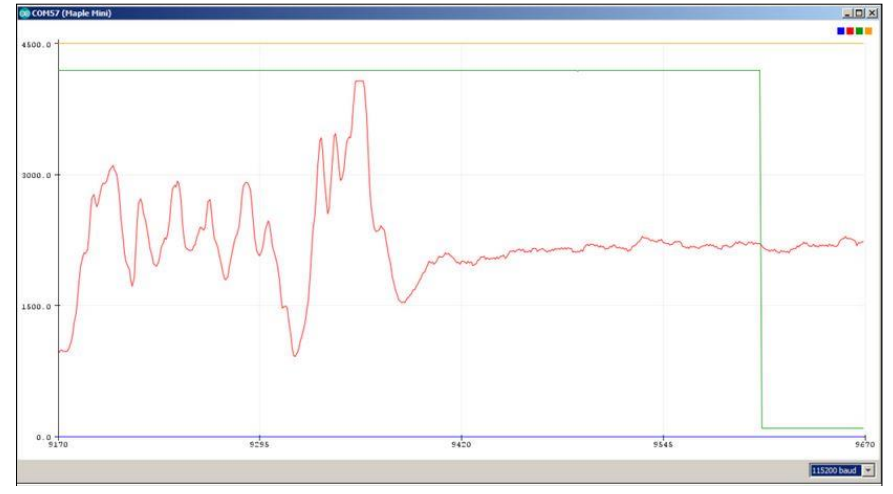

Gambar 13. Tampilan plot ketika membaca pergerakan yang terhenti

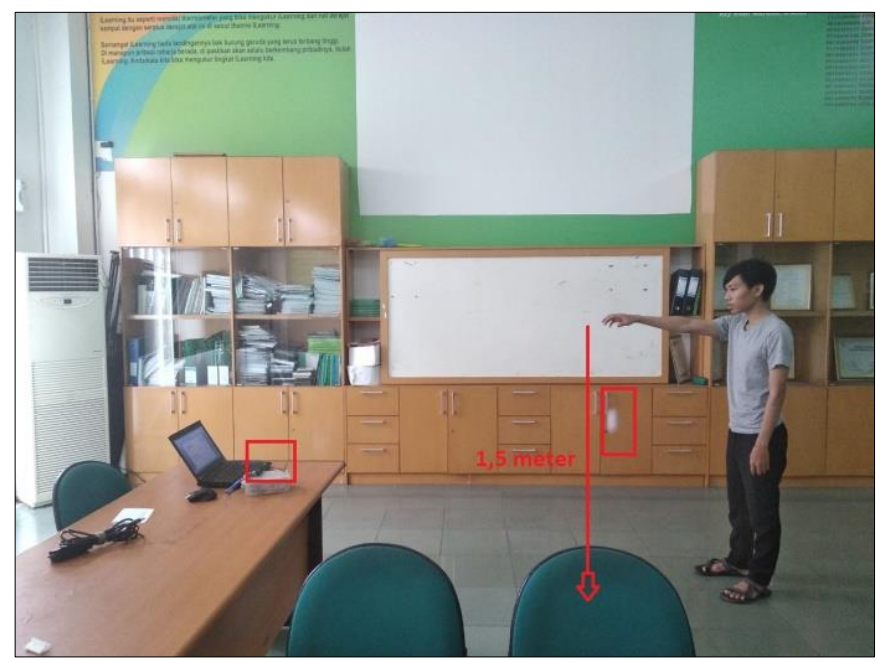

Gambar 14. Uji coba ketiga dengan menjatuhkan benda

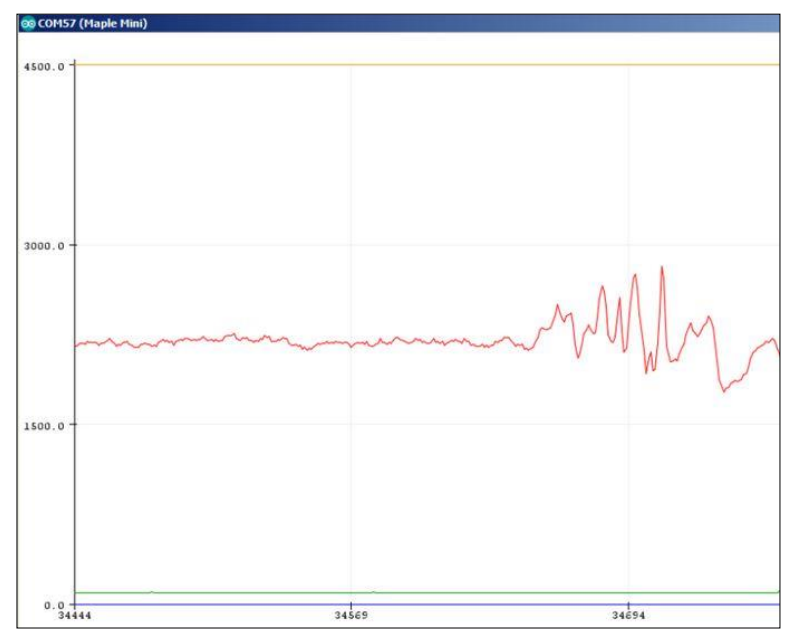

Gambar 15. Tampilan plot ketika membaca pergerakan benda terjatuh

\section{B. Penerapan Pada Aplikasi Blynk}

Pada aplikasi Blynk untuk bisa menampilkan grafik digunakan widget SuperChart dan hasil pengukuran nilai dari beberapa pergerakan objek ditunjukkan pada Gambar 16 hingga Gambar 18. Data yang dihasilkan oleh keluaran sensor RCWL 0516 pada aplikasi Blynk dengan yang sebenarnya memiliki selisih 1 detik. 


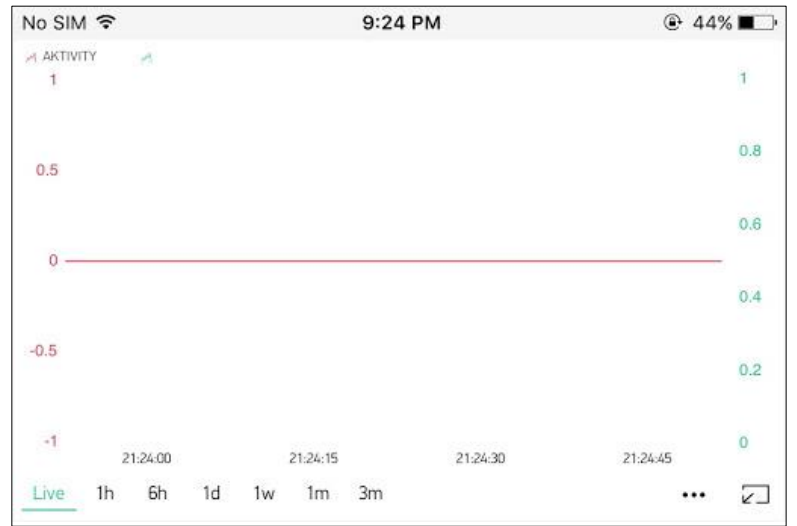

Gambar 16. Grafik tidak ada pergerakan

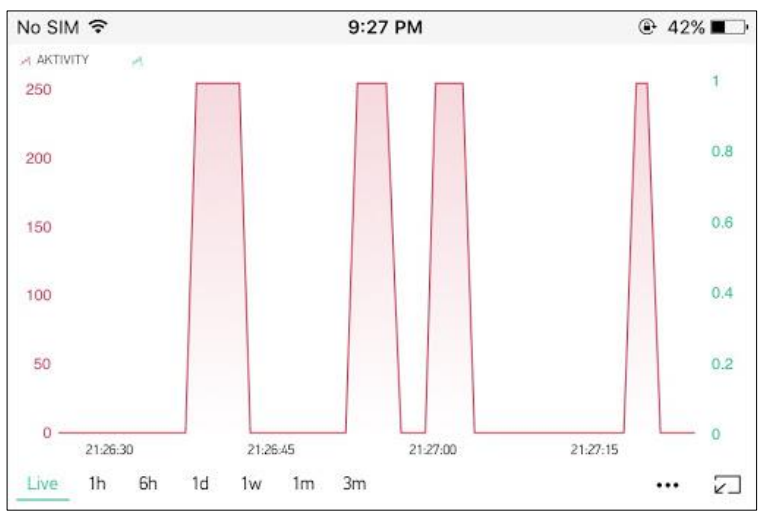

Gambar 17. Grafik ketika ada sedikit pergerakan

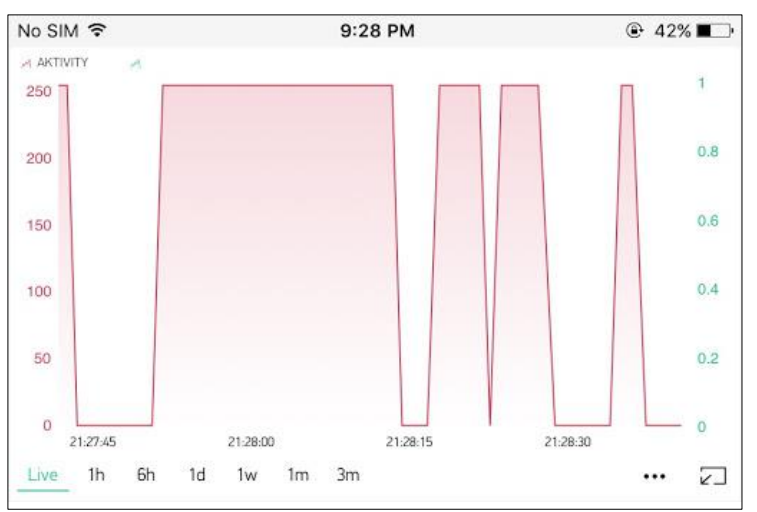

Gambar 18. Grafik ketika terbaca banyak pergerakan

\section{IV.PENUTUP}

\section{A. Simpulan}

Berdasarkan hasil penelitian yang telah dilakukan dapat disimpulkan bahwa:

1. Alat ini mendeteksi adanya pergerakan objek berjarak 2 sampai 4 meter dari lokasi sensor.

2. Alat ini memiliki selisih 1 (satu) detik antara hasil output sensor dengan tampilan pada aplikasi Blynk.

3. Interface alat ini dapat diakses secara online melalui gadget seperti handphone atau tablet.

4. Alat ini lebih unggul dari segi deteksi gerak dibanding alat keamanan kamera, sensor PIR dan ultrasonik karena tidak memacu pada cahaya, suhu tubuh ataupun posisi objek dengan sensor.

B. Saran

Saran untuk pengembangan selanjutnya adalah:

1. Alat ini masih bisa dikembangkan dari sisi desain maupun komponen yang digunakan.

2. Dapat dikembangkan pada tahap implementasi dengan menggunakan lebih banyak sensor RCWL 0516 pada satu alat untuk menambah tingkat keakuratan.

3. Perlu menambahkan daya listrik sementara atau backup energy yang memadai jika terjadi pemadaman listrik mendadak.

\section{REFERENSI}

[1] R. Ramadhan, Pendeteksi Obyek di dalam Ruangan Menggunakan Sensor Infra Merah, 2012.

[2] C. Laksana, D. A. Prasetya, dan B. Baidowi, Sistem Keamanan Ksatrian dengan Sensor PIR Menggunakan Metode Cluster Based. Prosiding SNATIF, 259-266, 2017.

[3] U. Rahardja, A. Saefullah, dan M. Ramdani, Simulasi Sistem Kendali Kecepatan Mobil Secara Otomatis, 2009.

[4] U. Rahardja, Q. Aini, dan N. Enay, Optimalisasi Dashboard pada Sistem Penilaian Sebagai Media Informasi di Perguruan Tinggi, SISFOTENIKA, 7(2), pp.167-176, 2017.

[5] A.Widya dan H. N. Isnianto, Kontrol Relay Melalui WiFiESP8266 dengan Aplikasi Blynk Berbasis OS Android (Doctoral dissertation, Universitas Gadjah Mada), 2016.

[6] I. Handayani, Pemanfaatan Sistem iMe (iLearning Media) dan Rinfo (Raharja.info) dalam penerapan Sistem E-Journal di CCIT Journal pada Perguruan Tinggi Raharja, 2015.

[7] U. Rahardja, Q. Aini, dan D. Sartika, Build a Business to Customer Online Store using Airzone Content Management System, 2015.

[8] (2018) The Arduino website. [Online]. Available: https://www.arduino.cc/

[9] (2018) The ESP8266 website. [Online]. Available: https://www.esp8266.com

[10] (2018) The Blynkwebsite. [Online]. Available: http://docs.blynk.cc/ 